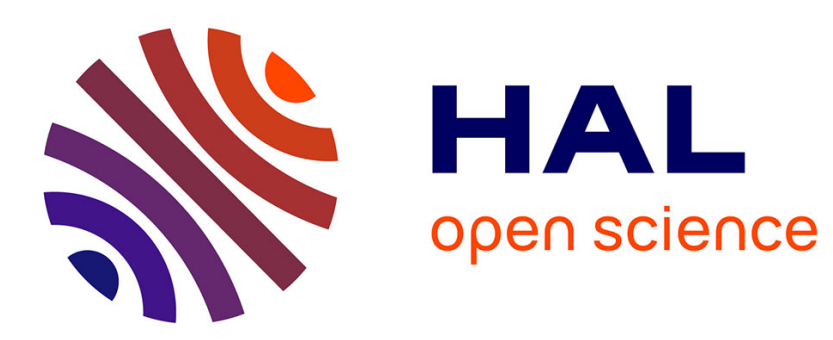

\title{
Tumor necrosis factor alpha-mediated inhibition of erythropoiesis involves GATA-1/GATA-2 balance impairment and PU.1 over-expression
}

Christine Grigorakaki, Franck Morceau, Sébastien Chateauvieux, Mario Dicato, Marc Diederich

\section{To cite this version:}

Christine Grigorakaki, Franck Morceau, Sébastien Chateauvieux, Mario Dicato, Marc Diederich. Tumor necrosis factor alpha-mediated inhibition of erythropoiesis involves GATA-1/GATA-2 balance impairment and PU.1 over-expression. Biochemical Pharmacology, 2011, 10.1016/j.bcp.2011.03.030 . hal-00703551

\section{HAL Id: hal-00703551 \\ https://hal.science/hal-00703551}

Submitted on 3 Jun 2012

HAL is a multi-disciplinary open access archive for the deposit and dissemination of scientific research documents, whether they are published or not. The documents may come from teaching and research institutions in France or abroad, or from public or private research centers.
L'archive ouverte pluridisciplinaire HAL, est destinée au dépôt et à la diffusion de documents scientifiques de niveau recherche, publiés ou non, émanant des établissements d'enseignement et de recherche français ou étrangers, des laboratoires publics ou privés. 


\section{Accepted Manuscript}

Title: Tumor necrosis factor alpha-mediated inhibition of erythropoiesis involves GATA-1/GATA-2 balance impairment and PU.1 over-expression

Authors: Christine Grigorakaki, Franck Morceau, Sébastien Chateauvieux, Mario Dicato, Marc Diederich

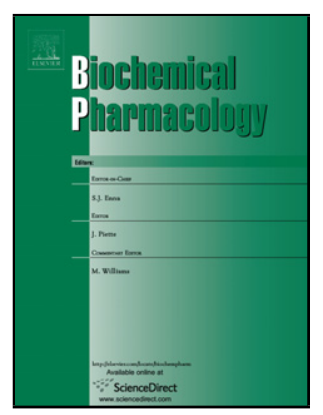

PII: S0006-2952(11)00217-6

DOI: doi:10.1016/j.bcp.2011.03.030

Reference: BCP 10870

To appear in: $\quad B C P$

Received date: $\quad 22-12-2010$

Revised date: 27-3-2011

Accepted date: $\quad 31-3-2011$

Please cite this article as: Grigorakaki C, Morceau F, Chateauvieux S, Dicato M, Diederich M, Tumor necrosis factor alpha-mediated inhibition of erythropoiesis involves GATA-1/GATA-2 balance impairment and PU.1 over-expression, Biochemical Pharmacology (2010), doi:10.1016/j.bcp.2011.03.030

This is a PDF file of an unedited manuscript that has been accepted for publication. As a service to our customers we are providing this early version of the manuscript. The manuscript will undergo copyediting, typesetting, and review of the resulting proof before it is published in its final form. Please note that during the production process errors may be discovered which could affect the content, and all legal disclaimers that apply to the journal pertain. 
Tumor necrosis factor alpha-mediated inhibition of erythropoiesis involves GATA1/GATA-2 balance impairment and PU.1 over-expression

Christine Grigorakaki, Franck Morceau, Sébastien Chateauvieux, Mario Dicato, Marc Diederich*

Laboratoire de Biologie Moléculaire et Cellulaire du Cancer, Hôpital Kirchberg, 9, Rue Edward Steichen, L-2540 Luxembourg, Luxembourg

* Corresponding Author: Marc Diederich

Postal address: Hôpital Kirchberg, 9, Rue Edward Steichen, L-2540 Luxembourg, Luxembourg

Tel.: +352 24684040

Fax: +35224684060

E-mail address: marc.diederich@,1bmcc.lu 


\begin{abstract}
Many physiological perturbations can cause anemia. In cancer patients, activation of the immune system leads to the production of proinflammatory cytokines including tumor necrosis factor alpha $(\mathrm{TNF} \alpha)$, that have been shown to inhibit red-cell production via poorly understood mechanisms. Treatment of anemia by human recombinant erythropoietin (EPO) is strongly suspected to induce tumor growth.

This study focuses on the mechanisms involved in TNF $\alpha$-mediated inhibition of erythropoiesis. CD34 ${ }^{+}$hematopoietic stem/progenitor cells (HSPC) were isolated from human cord blood. Erythropoiesis was achieved in vitro by stimulating cells with EPO. We show that TNF $\alpha$ clearly affected erythroid development, as assessed by May-Grünwald/Giemsa staining, flow cytometry analysis and fluorescent microscopy. The amount of hemoglobinproducing cells as well as the expression of GATA-1 target erythro-specific genes (EPO receptor, glycophorin A and globins) was found decreased after TNF $\alpha$ treatment of HSPC. In correlation, TNF $\alpha$ induced the expression of the transcription factors GATA-2 and PU.1, described as inhibitors of erythropoiesis. In this regard, TNF $\alpha$ promoted the formation of the GATA-1/PU.1 complex that has been reported to block the transcriptional activity of GATA1. Our results clearly demonstrate that TNF $\alpha$ prevents EPO-mediated erythropoiesis of HSPC as an early event, by directly affecting erythroid cell development.
\end{abstract}

Keywords: anemia; inflammation; TNF $\alpha$; GATA-1; GATA-2; PU.1 


\section{Introduction}

The majority of tumors are largely infiltrated by inflammatory cells, such as myelomonocytes and macrophages [1]. In response to the inflammatory environment, these cells produce inflammatory mediators including chemokines and cytokines. These mediators are tightly associated with cancer progression in combination with genetic alterations [2]. One of them, the Tumor Necrosis Factor alpha (TNF $\alpha)$, is widely found in the inflammationassociated cancer microenvironment [3-6]. Interestingly, because TNF $\alpha$ is commonly present in cancer and inflammatory diseases, it has been implicated in cancer- and inflammationrelated anemia. Indeed, patients suffering from cancer and chronic inflammation are often anemic [7]. Moreover, in vitro and in vivo studies have led to the conclusion that TNF $\alpha$ inhibits hematopoietic progenitors from undergoing erythroid differentiation [8-15]. Anti$\mathrm{TNF} \alpha$ treatment is effectively used for the treatment of chronic inflammatory diseases, but leads to increased risk of infection [16, 17]. Despite the beneficial effects of anti-TNF $\alpha$, this treatment may promote different types of cancers $[18,19]$.

Several events may trigger anemia, including iron deficiency, hemolysis and hemorrhage. In non-hematopoietic cancer, anemia can also result from the activation of the immune system with the release of inflammatory cytokines that affect red-cell production in patients. So far, one well described effect of cytokine release is the reduction of erythropoietin synthesis by kidneys [20]. In this specific case, anemia is usually treated with human recombinant EPO (EPO). Nevertheless, this treatment addresses only the symptoms, not the cause of the anemia. Furthermore, EPO can provoke cardiovascular and thrombo-embolic side effects, as well as possible tumor progression [21-24]. Indeed, cancer cells in many tumor types express the Erythropoietin receptor (EPOR) [25], and the interaction between Erythropoietin and the EPOR can activate the expression of genes implicated in angiogenesis 
and cell proliferation [26]. Additionally, anemic patients without Erythropoietin deficiency do not respond to EPO treatment $[27,28]$.

Erythropoiesis is a tightly regulated process by which red blood cells are generated from hematopoietic stem and progenitor cells (HSPCs). The development and maturation of erythroid cells requires Erythropoietin, which activates several signaling pathways by acting on its specific receptor, EPOR [29, 30]. These pathways are involved in cell proliferation, survival and differentiation [31-34]. Erythropoiesis is regulated by the combined action of transcription factors $[35,36]$. Indeed, the expression of erythroid specific genes is regulated by the major erythroid transcription factor, GATA-1 [37], which is involved in the terminal maturation and survival of erythroid cells. As previously shown, erythropoeisis is arrested when GATA-1 is inactivated, which leads to increased susceptibility of mouse embryos to death by anemia $[38,39]$. GATA-2, another member of the GATA family of transcription factors, acts as a balance to GATA-1 and is crucial during the earliest stages of erythropoiesis [40]. In addition, GATA-2 controls the self-renewal of erythroid progenitors in bone marrow [40-42]. These two factors act dynamically on hematopoietic progenitors during erythroid commitment $[43,44]$.

GATA-1 transcriptional activity is also modulated by co-factors [37] and posttranslational modifications [42]. One GATA-1 co-factor of interest is PU.1/SPi1, from the Ets-family of transcription factors, that plays a critical role in the balance between myelomonopoiesis and lymphopoiesis on the one side, and erythropoiesis on the other side [45]. Indeed, PU.1 and GATA-1 can physically interact in progenitor cells, leading to inactivation of GATA-1 and therefore the down-regulation of erythroid specific genes [46].

The mechanisms involved in TNF $\alpha$-mediated inhibition of erythropoiesis are not fully understood. Our previous studies showed that TNF $\alpha$ inhibits erythroid differentiation of human leukemia cell lines in culture. This suggests that the cytokine can act directly on 
hematopoietic cells independently from Erythropoietin deficiency. We reported that TNF $\alpha$ prevented the induction of erythroid differentiation in correlation with decreased expression of erythroid-specific genes and perturbations to the balance between GATA-1 and GATA-2 $[13-15]$.

In the present work, we studied the effect of TNF $\alpha$ on the development of CD34 HSPCs in the presence of EPO. In this model, different steps of erythropoiesis were successfully reproduced in vitro. We show that, in the heterogeneous cell population that constitutes the $\mathrm{CD}^{+} 4^{+}$HSPC culture, TNF $\alpha$ acts on EPO-treated HSPCs by perturbing erythroid development. This effect was found to correlate with changes in the key transcription factors, GATA-1, GATA-2 and PU.1. Moreover the direct effect of TNF $\alpha$ on erythroid progenitors has been confirmed by analyzing erythrospecific markers in isolated erythroid $\left(\mathrm{GPA}^{+}\right)$cells. 


\section{Materials and methods}

\subsection{Cell culture and treatment}

Human umbilical cord blood was obtained from the Clinique Bohler in Luxembourg. For ethical reasons, cord blood cells were collected with written informed consent for use in research in agreement with the National Committee of Research Ethics in Luxembourg. The blood was collected in heparinized tubes. The mononucleated cell fraction was isolated using Ficoll $^{\mathrm{TM}}$ (GE Healthcare, Roosendaal, The Netherlands) density gradient medium. CD34 ${ }^{+}$ HSPCs or $\mathrm{GPA}^{+}$cells were selected using magnetic cell sorting. Purification was performed following the manufacturer's instructions (MACS Miltenyi, Utrecht, The Netherlands). The average purity of the cells obtained was around $96 \%$ of CD $34^{+}$cells.

After isolation, the cells were cultured in serum-free culture medium for cell expansion and erythroid differentiation (Stem Cell II, Sigma-Aldrich, Bornem, Belgium), to which a cytokine cocktail containing Interleukin 3 (IL3, Reliatech, Wolfenbüttel, Germany) and stem cell factor (SCF, Reliatech) was added. Interleukin $3(10 \mathrm{ng} / \mathrm{mL})$ was added together with SCF (10 ng/mL) for 3 days following $\mathrm{CD} 4^{+}$cell enrichment. Erythroid differentiation was achieved by adding $2 \mathrm{U} / \mathrm{mL}$ human recombinant erythropoietin (EPO) (Eprex, a kind gift of Janssen-Cilag) to the medium. EPO was added on day 0, whereas IL3 was removed on day 4 and SCF was removed on day 6 . The medium was also supplemented with L-glutamine and penicillin/streptomycin (Lonza, Vervier, Belgium). The cells were maintained at $2 \times 10^{5}$ cells/mL. TNF $\alpha$ (20 ng/mL; ReliaTech) was added $1 \mathrm{~h}$ before EPO (Figure S1A).

K562 and TF1 cells were provided by DSMZ (Deutsche Sammlung für Mikroorganismen und Zellkulturen; Braunschweig, Germany). These cells were cultured and treated as previously described $[13,15]$. All cells were kept in $5 \% \mathrm{CO}_{2}$ at $37^{\circ} \mathrm{C}$. 


\subsection{Assays of cell proliferation, viability and morphology and erythroid differentiation}

Cell number and viability were assessed using trypan blue dye exclusion. For evaluation of cell morphology, cytospin preparations were stained with May-Grünwald/Giemsa solution (Merck, Leuven, Belgium). Benzidine staining was used to detect the pseudoperoxidase activity of hemoglobin in cells. Images were collected with a Leica DM 2000 microscope.

\subsection{Flow cytometry}

HSPCs $\left(2 \times 10^{5}\right)$ were washed three times in PBS, before incubation with $5 \mu \mathrm{L}$ of antibody for 90 min at $4{ }^{\circ} \mathrm{C}$. FITC-labeled CD34 (clone 8G12) and CD41a (clone HIP8), PElabeled CD11b (clone D12), CD36 (clone CB38), and CD38 (clone HB7) and PE-Cy ${ }^{\mathrm{TM}_{5}}$ labeled GPA (235a; clone HIR2) antibodies were used (BD Biosciences, Erembodegem, Belgium). The corresponding isotype control antibodies (BD Biosciences) were used to set the gating levels. The samples were fixed with $2 \%$ formaldehyde after being washed twice with 1X PBS. Analysis was performed on a FACS Calibur flow cytometer (BD Biosciences). The statistical analysis was based on 10,000 events per sample using FlowJo ${ }^{\circledR}$ software (version 8.8.7, Tree Star, Ashland Oregon, USA).

\subsection{Fluorescence microscopy}

HSPCs $\left(5 \times 10^{5}\right)$ were washed three times in PBS. Cell pellets were then resuspended in $100 \mu \mathrm{L}$ of $1 \mathrm{X}$ PBS containing $3 \mu \mathrm{L}$ of GPA antibody (235a; clone HIR2; BD Biosciences) and incubated for $2 \mathrm{~h}$ at $4{ }^{\circ} \mathrm{C}$. After washing three times with 1X PBS, cells were fixed with 2\% formaldehyde and stained with Hoechst $33342(1 \mu \mathrm{g} / \mathrm{mL}$; Merck, Leuven, Belgium). Five microliters of stained cells were mounted on slides and observed with an Olympus CellM fluorescent microscope (Aartselaar, Belgium).

\subsection{Western blotting}

Up to $4 \times 10^{6}$ HSPCs were used to prepare nuclear, cytoplasmic and total protein 
extracts, as previously described [15]. Denatured proteins (10 $\mu \mathrm{g}$ or $20 \mu \mathrm{g})$ were separated on an SDS-PAGE gel. The proteins were transferred to a PVDF membrane that was then saturated for $1 \mathrm{~h}$ in 5\% BSA or non-fat dry milk in PBS-Tween20 (PBS-T). The membranes were probed with antibodies against GATA-1 (C20X), GATA-2 (H-116), PU.1 (T-21), EPOR (M20), $\alpha$-globin, $\beta$-globin, $\gamma$-globin (Santa Cruz Biotechnology, Tebu Bio, Boechout, Belgium) and $\beta$ actin (AC-15, Sigma-Aldrich). After washing with PBS-T, the membranes were incubated with peroxidase-conjugated antibodies (Santa Cruz Biotechnology). The proteins were then visualized using chemiluminescence detection (ECL, GE Healthcare) and were revealed by autoradiography. Chemiluminescence was analyzed with the Kodak image station 440 CF (Kodak, Analis, Suarlée, Belgium) and quantified with the Kodak 1D image analysis software. The fold change of relative protein expression was normalized to the internal control, $\beta$ actin.

\subsection{Immunoprecipitation assays}

Immunoprecipitation assays were performed using MACS protein G microbeads from MACS Miltenyi. Two hundred micrograms of nuclear and cytoplasmic proteins obtained from primary hematopoietic cells were incubated with $100 \mu \mathrm{L}$ of protein $\mathrm{G}$ beads and $2 \mu \mathrm{g}$ of GATA-1 (C20X) antibody (Santa Cruz Biotechnology). This mixture was mixed gently overnight at $4{ }^{\circ} \mathrm{C}$. The immune complex was immobilized in a microMACS separation column and isolated according to the manufacturer's instructions. Immunoprecipitated proteins were loaded in an SDS-PAGE electrophoresis gel followed by western blot with GATA-1 (N1) and PU.1 (T-21) antibodies (Santa Cruz Biotechnology).

\subsection{Electrophoretic mobility shift assay}

Ten micrograms of nuclear extracts from TF1 or HSPCs was incubated for 30 min on ice with $\left[{ }^{32} \mathrm{P}\right] \mathrm{ATP}-$ labeled oligonucleotides in a reaction mixture containing protease inhibitors, $10 \mathrm{mM}$ Tris- $\mathrm{HCl}, \mathrm{pH} 8.5,5 \%$ glycerol, $50 \mathrm{mM} \mathrm{NaCl}, 0.5 \mathrm{mM}$ EDTA, $0.5 \mathrm{mM}$ 
DTT, $1 \mathrm{mM} \mathrm{MgCl}_{2}, 2.5 \mathrm{mM}$ poly(dI-dC), $0.2 \mathrm{mg} / \mathrm{mL}$ BSA and $4 \mathrm{mg} / \mathrm{mL}$ spermidine. For supershift the nuclear extracts and labeled oligonucleotide probes were incubated with the reaction mixture for $30 \mathrm{~min}$ on ice prior to $30 \mathrm{~min}$ incubation with $2 \mu \mathrm{g}$ p50 (H119X) and p65 (C20X) antibodies (Santa Cruz Biotechnology). The sequence of the NFkB probe was: sense 5'-AGTTGAGGGACTTTCCCAGGC-3'. The corresponding binding site is underlined. Annealing and labeling was performed as described previously [15].

\subsection{Real time PCR}

RNA was extracted from $3 \times 10^{6}$ EPO-stimulated CD34 ${ }^{+}$cells treated with TNF $\alpha$ or left untreated, using Trizol (Invitrogen, Merelbeke, Belgium) and cleaned using RNeasy Mini Kit (Qiagen, Venlo, The Netherlands). RNA quantity was measured by spectrophotometry (Nanodrop ${ }^{\circledR}$ ND-1000).

The RT ${ }^{2}$ PCR Array First Strand Kit (SuperArray, Tebu-Bio, Boechout, Belgium) was used to synthesize cDNA from $1.5 \mu \mathrm{g}$ of RNA according to the manufacturer's instructions. Real time PCR was performed using a customized RT ${ }^{2}$ Profiler PCR Array System kit and the primers listed in Table S1 according to the manufacturer's instructions. The samples were analyzed in a 7300 Real Time PCR system (Applied Biosystems, Halle, Belgium). The results were calculated using the $\triangle \mathrm{CT}$ method and were normalized to the GAPDH housekeeping gene.

\subsection{Transient transfection assays and plasmids}

TF1 cells $\left(3.75 \times 10^{6}\right)$ were electroporated using the Gene Pulser (BioRad, Nazareth, Belgium). Each pulse was made at $250 \mathrm{~V}$ and $950 \mu \mathrm{F}$ with $5 \mu \mathrm{g}$ of DNA in a medium added to $0.1 \%$ SVF. The reporter plasmids under the control of GATA-1 is pGL3-GATA-Luc [47] whereas the Renilla-expressing pHRG-TK plasmid (Promega, Leiden, The Netherlands) was used as an internal control. The pXM-GATA1 expressing vector was used to express 
exogenous GATA-1 in TF1 cells [48]. Twenty-four hours after transfection, the cells were seeded at $1 \times 10^{6}$ cell $/ \mathrm{mL}$ and treated with $20 \mathrm{ng} / \mathrm{mL}$ of TNF $\alpha$ for $2 \mathrm{~h}$. Dual-Glo ${ }^{\mathrm{TM}}$ Luciferase Reagent and Dual-Glo ${ }^{\mathrm{TM}}$ Stop\&Glow Reagent (Promega) were used according to the manufacturer's instructions. Luciferase activities (Firefly and Renilla) were measured with an Orion microplate luminometer (Berthold). Firefly activity was normalized to Renilla and results were expressed as a ratio in arbitrary units.

\subsection{Statistics}

Data are expressed as mean \pm S.D. and were analyzed by Student's t-test. Results were considered statistically significant when $* \mathrm{P}<0.05,{ }^{*} \mathrm{P}<0.01$ and $* * * \mathrm{P}<0.001$. 


\section{Results}

\subsection{TNF $\alpha$ affects EPO-mediated erythroid development of $\mathrm{CD}^{+} 4^{+}$cells}

$\mathrm{CD}^{+} 4^{+}$HSPCs were isolated from umbilical cord blood to an average purity of approximately $96 \%$ (Figure 1). Following $\mathrm{CD}^{+} 4^{+}$isolation, cell populations were characterized by analyzing specific hematopoietic markers with flow cytometry. As expected, results show a heterogeneous population with erythro-, myelo-, megakaryo- and lymphoblastic features (Figure 1). The cell culture procedure used to study the effect of TNF $\alpha$ on EPO-mediated erythropoiesis was designed as described in Figure S1A. The culture medium was supplemented with $20 \mathrm{ng} / \mathrm{mL}$ TNF $\alpha$ on days 0,4 and $6,1 \mathrm{~h}$ before EPO stimulation. As shown in the control EMSA experiment, NF- $\kappa$ Bp50/p65 was activated in TNF $\alpha$-treated cells, indicating that $\mathrm{CD}^{+} 4^{+}$cells are sensitive to TNF $\alpha$ (Figure S1B). Moreover, the percentage of $\mathrm{CD} 4^{+}$cells significantly decreased from day 4 to day 9 of treatment with EPO alone and EPO/TNF $\alpha$ (Figure S1C). This suggests that cells underwent differentiation.

As shown by May-Grünwald/Giemsa staining, EPO successfully induced erythropoiesis in vitro (Figure 2A). The different stages of cell maturation during erythropoiesis were observed, including reticulocyte-like cells and enucleation at days 5 and 8 . TNF $\alpha$ treatment prevented EPO-mediated development of erythropoiesis so that the different stages of erythroblast maturation were not observed. Moreover, TNF $\alpha$ treatment triggered a $50 \%$ decrease in the percentage of hemoglobin producing cells (benzidine positive cells) after 4 days of treatment (Figure 2B). Flow cytometry confirmed the effect of TNF $\alpha$ on the erythroid pathway. The early erythroid marker, CD36, was significantly down-regulated in TNF $\alpha$-treated cells in comparison to the control EPO-treated cells on day 9. Likewise, the 
expression of GPA, another erythro-specific marker, was significantly decreased by 2.8 -fold on day 9 of TNF $\alpha$ treatment (Figure 2C). This down-regulation was also observed by fluorescent microscopy, as fluorescent intensity was lower in TNF $\alpha$-treated cells (Figure S2). Similarly, flow cytometry showed a decrease in the percentage of $\mathrm{GPA}^{+}$cells after 4 and 9 days of TNF $\alpha$ treatment (Figure 2C). Together, results showed that TNF $\alpha$ reduced both the percentage of $\mathrm{GPA}^{+}$cells and the expression level of GPA in these cells. Moreover, megakaryocytic CD41a and myelo-monocytic CD11b, as well as neutrophil CD10, eosinophil CD15 and macrophage CD16 markers were not affected (data not shown). Furthermore, we observed that TNF $\alpha$ increased cell proliferation (Figure 2D). Altogether, our results provide evidence that TNF $\alpha$ significantly prevents EPO-mediated erythroid differentiation of HSPCs in our culture system.

\subsection{TNF $\alpha$ inhibits GATA-1 transactivation in TF1 cells}

GATA-1, a key transcription factor involved in erythroid differentiation, regulates the expression of erythroid-specific genes. The ability of TNF $\alpha$ to inhibit GATA-1 transactivation was assessed by transient transfection assay in an established cell line to circumvent the heterogeneity of HSPC culture. The human erythroleukemia TF1 cell line was co-transfected with the pXM-GATA1 expression vector together with a reporter plasmid containing GATA sequences within the promoter upstream of the luciferase reporter gene (pGL3-GATA-Luc). After $24 \mathrm{~h}$ of transfection, the cells were treated with TNF $\alpha$ or left untreated for $2 \mathrm{~h}$ in medium containing granulocyte macrophage-colony stimulating factor (GM-CSF). Luciferase activity was increased 2-fold in cells transfected with pXM-GATA1. Results show that the exogenous GATA-1-mediated luciferase activation was significantly reduced in the presence of TNF $\alpha$ compared to basal levels, suggesting a direct effect of the cytokine on GATA-1 transactivation (Figure 3A). This effect may be considered to be 
independent from the expression level of endogenous GATA-1 in these culture conditions because GATA-1 had low basal expression in TF1 cells (Figure 3B).

\subsection{TNF $\alpha$ affects the expression of GATA-1, GATA-2 and PU.1}

The effect of TNF $\alpha$ on GATA-1 expression, as well as other transcription factors critical for erythroid development, was then studied in EPO-differentiated HSPCs. Despite the inhibiting effect of TNF $\alpha$ on erythropoiesis, real-time PCR revealed a 1.5 -fold increase in GATA-1 mRNA expression after 4 days of TNF $\alpha$ treatment. However, a 2.7-fold increase in GATA-2 and 2.3-fold-increase in PU.1 were also observed after TNF $\alpha$ treatment (Figure 4A). GATA-2 and PU.1 over-expression on the one hand and a perturbation of the balance between GATA-1 and GATA-2 on the other hand, are in accordance with inhibition of erythropoiesis. Moreover, GATA-2 over-expression was correlated with increased cell proliferation (Figure 2D). Western blot analysis of the transcription factors validated the realtime PCR results as GATA-1 expression was increased (up to 2.9-fold) in TNF $\alpha$-treated HSPCs on days 2, 3 and 4. Likewise, GATA-2 and PU.1 showed a 2.8- and 2.3-fold maximal increase in expression, respectively (Figure 4B). These results suggest that TNF $\alpha$ mediates its inhibiting effect by affecting transcription factors associated with GATA-1, rather than GATA-1's expression level.

\subsection{Effect of TNF $\alpha$ on the interaction between GATA-1 and PU.1}

PU.1 and GATA-1 are described as physically interacting with each other, which results in the inhibition of GATA-1 transactivation and, therefore, the down-regulation of erythroid specific genes [49]. To assess the possible capacity of TNF $\alpha$ to affect GATA-1 activity via PU.1 over-expression, the interaction between GATA-1 and PU.1 was studied by immunoprecipitation assay in HSPCs that had undergone EPO-mediated differentiation in the presence or absence of TNF $\alpha$. The results show that PU.1 co-immunoprecipitated with 
GATA-1 in the nuclear protein extracts from TNF $\alpha$-treated HSPCs after 4 days, whereas it did not in control cells (Figure 4C). This result suggests that PU.1 contributes to TNF $\alpha$ mediated inhibition of erythropoiesis by directly interacting with GATA-1.

\subsection{TNF $\alpha$ down-regulates erythro-specific gene expression}

To correlate the inhibiting effect of TNF $\alpha$ on GATA-1 activity with GATA-1 target gene expression, we analyzed glycophorin A (GPA), EPOR and globin ( $\alpha, \beta$ and $\gamma)$ gene expression in EPO- and EPO/TNF $\alpha$-treated HSPCs at both the mRNA and protein levels. All the genes studied were found to be down-regulated in the presence of TNF $\alpha$ in comparison to EPO-differentiated cells that were not treated with TNFa. Real-time PCR analysis showed a 2-fold decrease in GPA, EPOR, $\alpha$-globin, $\beta$-globin and $\gamma$-globin mRNA levels after 4 days of TNF $\alpha$ treatment. Conversely, the expression of CD11b, a monocyte/macrophage differentiation-related gene and CD41b, a megakaryocyte differentiation-related gene, were not significantly affected (Figure 5A). Western blot analysis showed a 2-fold reduced expression of EPOR protein at days 3 and 4. Globins were not detectable or only slightly expressed after two days of TNF $\alpha$ treatment in comparison to EPO-stimulated cells without $\mathrm{TNF} \alpha$ treatment. The expression of globins progressively increased in EPO-treated and EPO/TNF $\alpha$-treated cells over the 4 days of treatment. However, $\alpha$ - and $\beta$-globin expression levels remained lower in the presence of TNF $\alpha$. The inhibition of $\gamma$-globin observed on day 2 of TNF $\alpha$ treatment was abolished on days 3 and 4 (Figure 5B). These results are in agreement with the decrease in erythroblastic cell population in culture, supporting the inhibitory effect of TNF $\alpha$ on erythroid cell development via a down-regulation of GATA-1 erythro-specific target genes.

\subsection{TNF $\alpha$ acts directly on erythroid cells}


To verify the direct effect of TNF $\alpha$ on erythroid progenitors, HSPC were stimulated by EPO with or without TNF $\alpha$ treatment. Cells were treated for 9 days based on the results of flow cytometry. This result showed a more important inhibitory effect of TNF $\alpha$ on GPA expression level at day 9 compared to day 4 (Figure 2C, GPA, MFI=f (days of treatment)). $\mathrm{GPA}^{+}$cells were isolated and Western blot analysis showed that GATA-1, GATA-2 and PU.1 expression remained over-expressed in TNF $\alpha$-treated cells. Moreover, globin expression remained lower in these cells compared to EPO-stimulated cells (Figure 6). This is in agreement with a delay of erythroid differentiation and correlates with the low expression of GPA as shown in figure $2 \mathrm{C}$ and $\mathrm{S} 2$. Results demonstrate that TNF $\alpha$ inhibits erythroid development through a direct effect on early erythroid progenitors. 


\section{Discussion}

We used CD $34^{+}$HSPCs purified from umbilical cord blood, which are commonly used in vitro to mimic erythropoiesis, in order to investigate the effect of $\mathrm{TNF} \alpha$ on erythropoiesis at the cellular and molecular levels. Cytometry revealed a heterogeneous $\mathrm{CD} 34^{+}$cell population detected in the culture prior to the addition of EPO or EPO/TNF $\alpha$. In this study, we successfully reproduced the different steps of EPO-mediated erythropoiesis, as assessed by May-Grünwald/Giemsa staining after several days of culture. The addition of TNF $\alpha$ to the medium clearly repressed erythroid development of $\mathrm{CD} 34^{+}$cells as confirmed by several methods. In contrast, the myeloid (granulo-monocytic) and megakaryocytic pathways were not affected. This experimental model is a simplification of the in vivo situation since it omits other mediators of inflammation that are involved in the development of anemia [50]. Nonetheless, the action of TNF $\alpha$ was observed in a heterogeneous hematopoietic cell population in which anemia was successfully mimicked. Indeed, TNF $\alpha$ specifically inhibited erythropoiesis by acting directly on HSPCs, likely by affecting EPO activity.

At the molecular level, this study indicates the effect of TNF $\alpha$ on the combination of transcription factors that leads to physiological hematopoietic lineage commitment [35-37]. In erythropoiesis, the GATA-1 and GATA-2 transcription factors have essential roles, and a quantitative balance in their protein levels is required to achieve erythroid lineage development [51]. GATA-2 plays a role in early progenitor cell proliferation, and activates GATA-1 gene expression, which, conversely, silences GATA-2 expression in erythroid progenitors [52]. GATA-1 deficiency leads to death due to severe anemia [38], while GATA2 deficiency leads to embryonic death [41]. Moreover, Ikonomi et al. reported that GATA-2 over-expression induced the arrest of erythroid differentiation in K562 cells [53]. However, it has also been reported that over-expression of GATA1 in erythroid cells, both in vitro, and in 
vivo, inhibits erythroid differentiation [54, 55]. In our in vitro culture system, GATA-1, and GATA-2 were both over-expressed, suggesting a deregulation of the balance between GATA1 and GATA-2 after TNF $\alpha$ treatment. The increase in GATA-2 expression could explain the over-expression of GATA-1 [43]. However, we previously reported increased expression of GATA-2 in combination with decreased expression of GATA-1 in EPO-induced TF1 cells in the presence of TNF $\alpha$ [13]. Observations were then in favor of a role for GATA-2 overexpression in the effect of TNF $\alpha$ on HSPCs. However, GATA-2 up-regulation by TNF $\alpha$ has also been described in the hepatocarcinoma cell line (HepG2) [56]. This effect was involved in the inhibition of Erythropoietin gene expression at the level of the kidney and liver, which could represent an alternate mechanism by which pro-inflammatory cytokines trigger anemia. Here, we provide evidence that TNF $\alpha$ can also inhibit erythropoiesis by directly affecting EPO-responsive HSPC erythroid differentiation.

To evaluate the effect of TNF $\alpha$ on GATA-1 transcriptional activity, exogenous GATA1 was transiently transfected together with the pGL3-GATA-Luc reporter plasmid in TF1 cells. The use of this cell line circumvented the heterogeneity of HSPC culture and the activation of the GATA responsive element within the reporter gene promoter by other members of the GATA family of transcription factors, including endogenous GATA-1 itself. Indeed, GATA-1 expression remains at a very low basal level in TF1 cells when cultured in GM-CSF containing medium. In the presence of TNF $\alpha$, the transcriptional activity of GATA1 was significantly reduced, such that the inhibiting effect was attributed to a direct alteration of GATA-1 transactivation by TNF $\alpha$. This effect could involve impairments in the posttranslational regulation of GATA-1, as we previously showed that TNF $\alpha$ reduced GATA1 acetylation in TF1 cells [13].

Moreover, GATA-1 activity is also dependent on interaction with co-factors. It has been reported that PU.1 inhibits erythroid differentiation by physically interacting with GATA-1 
and inhibiting its binding to the DNA of erythro-specific genes [46, 49, 57]. We show in this study that TNF $\alpha$ induced increased expression of the myeloid and lymphoid transcription factor, PU.1 [58, 59]. The analysis of GATA-1/PU.1 interaction by immunoprecipitation showed that the TNF $\alpha$-mediated increase in PU.1 expression was associated with the formation of the GATA-1/PU.1 complex in the nuclear extracts from EPO-induced HSPCs. These results support a critical role for PU.1 in TNF $\alpha$-mediated inhibition of erythropoiesis, likely by affecting GATA-1 activity in HSPCs. In correlation with this proposal, TNF $\alpha$ mediated inhibition of erythropoiesis was associated with the down-regulation of only GATA-1 target genes. Furthermore, persistent over-expression of GATA-2 is in accordance with the decreased activity of GATA-1, as GATA-2 has been reported to be up-regulated in the absence of GATA-1 [60]. However, over-expression of GATA-2 might contribute to progenitor renewal.

Altogether, our results indicate that TNF $\alpha$ affects distinct regulatory steps that are implicated in erythroid maturation and differentiation. We show that TNF $\alpha$ plays a critical role in the impairment of the balance between GATA-1 and GATA-2. Moreover, we provide, for the first time, the evidence that TNF $\alpha$ induces PU.1 protein over-expression in HSPCs and perturbs the normal pattern of erythroid-implicated factors, thus promoting deregulation of lineage commitment despite the presence of EPO. Furthermore, the analysis of globin and transcription factor expression in $\mathrm{GPA}^{+}$erythroid cells after TNF $\alpha$ treatment of HSPCs supported the hypothesis of a direct effect of TNF $\alpha$ on erythroid progenitors.

Therefore, we suggest that cancer-related anemia results in part, from a direct interaction between HSPCs and pro-inflammatory cytokines released in the bone marrow and tumor microenvironment. According to our results this interaction triggers modifications in specific transcription factor networks implicated in the regulation of the different lineages commitment. While EPO is efficient for treating anemia associated with Erythropoietin 
deficiency, alternative therapies are obviously required in the case of direct TNF $\alpha$-mediated injury of erythroid development in the presence of functional Erythropoietin.

\section{Acknowledgements}

The authors thank E. Henry for technical assistance, C. Groos for helpful comments and the staff of the Clinique Bohler for collecting cord blood. This work was supported by Télévie, the Fondation de Recherche "Cancer et Sang" and "Recherches Scientifiques Luxembourg" asbl. CG was supported by an Aide Formation Recherche (AFR) grant of the Fonds National de la Recherche (FNR), Luxembourg. The authors thank the "Een Häerz fir Kriibskrank Kanner" asbl and the Action Lions "Vaincre le Cancer" for additional support. Print and editing costs were covered by the Fonds National de la Recherche (FNR), Luxembourg. 


\section{References}

[1] Sica A, Bronte V. Altered macrophage differentiation and immune dysfunction in tumor development. J Clin Invest 2007;117:1155-66.

[2] Mantovani A, Allavena P, Sica A, Balkwill F. Cancer-related inflammation. Nature $2008 ; 454: 436-44$

[3] Pikarsky E, Porat RM, Stein I, Abramovitch R, Amit S, Kasem S, et al. NF-kappaB functions as a tumour promoter in inflammation-associated cancer. Nature 2004;431:461-6.

[4] Friess H, Guo XZ, Nan BC, Kleeff O, Buchler MW. Growth factors and cytokines in pancreatic carcinogenesis. Ann N Y Acad Sci 1999;880:110-21.

[5] Balkwill F. Cancer and the chemokine network. Nat Rev Cancer 2004;4:540-50.

[6] Moore RJ, Owens DM, Stamp G, Arnott C, Burke F, East N, et al. Mice deficient in tumor necrosis factor-alpha are resistant to skin carcinogenesis. Nat Med 1999;5:82831.

[7] Knight K, Wade S, Balducci L. Prevalence and outcomes of anemia in cancer: a systematic review of the literature. Am J Med 2004;116 Suppl 7A:11S-26S.

[8] Johnson RA, Waddelow TA, Caro J, Oliff A, Roodman GD. Chronic exposure to tumor necrosis factor in vivo preferentially inhibits erythropoiesis in nude mice. Blood $1989 ; 74: 130-8$.

[9] Papadaki HA, Kritikos HD, Valatas V, Boumpas DT, Eliopoulos GD. Anemia of chronic disease in rheumatoid arthritis is associated with increased apoptosis of bone marrow erythroid cells: improvement following anti-tumor necrosis factor-alpha antibody therapy. Blood 2002;100:474-82. 
[10] Xiao W, Koizumi K, Nishio M, Endo T, Osawa M, Fujimoto K, et al. Tumor necrosis factor-alpha inhibits generation of glycophorin A+ cells by CD34+ cells. Exp Hematol 2002;30:1238-47.

[11] Dufour C, Corcione A, Svahn J, Haupt R, Poggi V, Beka'ssy AN, et al. TNF-alpha and IFN-gamma are overexpressed in the bone marrow of Fanconi anemia patients and TNF-alpha suppresses erythropoiesis in vitro. Blood 2003;102:2053-9.

[12] Dubey S, Shukla P, Nityanand S. Expression of interferon-gamma and tumor necrosis factor-alpha in bone marrow $\mathrm{T}$ cells and their levels in bone marrow plasma in patients with aplastic anemia. Ann Hematol 2005;84:572-7.

[13] Buck I, Morceau F, Cristofanon S, Heintz C, Chateauvieux S, Reuter S, et al. Tumor necrosis factor alpha inhibits erythroid differentiation in human erythropoietindependent cells involving p38 MAPK pathway, GATA-1 and FOG-1 downregulation and GATA-2 upregulation. Biochem Pharmacol 2008;76:1229-39.

[14] Buck I, Morceau F, Cristofanon S, Reuter S, Dicato M, Diederich M. The inhibitory effect of the proinflammatory cytokine TNFalpha on erythroid differentiation involves erythroid transcription factor modulation. Int J Oncol 2009;34:853-60.

[15] Morceau F, Schnekenburger M, Blasius R, Buck I, Dicato M, Diederich M. Tumor necrosis factor alpha inhibits aclacinomycin A-induced erythroid differentiation of K562 cells via GATA-1. Cancer Lett 2006;240:203-12.

[16] Haraoui B. Differentiating the efficacy of tumor necrosis factor inhibitors. J Rheumatol Suppl 2005;74:3-7.

[17] Vilcek J, Feldmann M. Historical review: Cytokines as therapeutics and targets of therapeutics. Trends Pharmacol Sci 2004;25:201-9.

[18] Yan L, Anderson GM, DeWitte M, Nakada MT. Therapeutic potential of cytokine and chemokine antagonists in cancer therapy. Eur J Cancer 2006;42:793-802. 
[19] Scheinfeld N. A comprehensive review and evaluation of the side effects of the tumor necrosis factor alpha blockers etanercept, infliximab and adalimumab. J Dermatolog Treat 2004;15:280-94.

[20] Spivak JL. The anaemia of cancer: death by a thousand cuts. Nat Rev Cancer 2005;5:543-55.

[21] Engert A. Recombinant human erythropoietin in oncology: current status and further developments. Ann Oncol 2005;16:1584-95.

[22] Rizzo JD, Somerfield MR, Hagerty KL, Seidenfeld J, Bohlius J, Bennett CL, et al. Use of epoetin and darbepoetin in patients with cancer: 2007 American Society of Hematology/American Society of Clinical Oncology clinical practice guideline update. Blood 2008;111:25-41.

[23] Bohlius J, Schmidlin K, Brillant C, Schwarzer G, Trelle S, Seidenfeld J, et al. Recombinant human erythropoiesis-stimulating agents and mortality in patients with cancer: a meta-analysis of randomised trials. Lancet 2009;373:1532-42.

[24] Tonelli M, Hemmelgarn B, Reiman T, Manns B, Reaume MN, Lloyd A, et al. Benefits and harms of erythropoiesis-stimulating agents for anemia related to cancer: a meta-analysis. CMAJ 2009;180:E62-71.

[25] Fandrey J. Erythropoietin receptors on tumor cells: what do they mean? Oncologist 2008;13 Suppl 3:16-20.

[26] Yasuda Y, Fujita Y, Matsuo T, Koinuma S, Hara S, Tazaki A, et al. Erythropoietin regulates tumour growth of human malignancies. Carcinogenesis 2003;24:1021-9.

[27] Cooper AC, Mikhail A, Lethbridge MW, Kemeny DM, Macdougall IC. Increased expression of erythropoiesis inhibiting cytokines (IFN-gamma, TNF-alpha, IL-10, and IL-13) by $\mathrm{T}$ cells in patients exhibiting a poor response to erythropoietin therapy. $\mathrm{J}$ Am Soc Nephrol 2003;14:1776-84. 
[28] Macdougall IC, Cooper AC. Hyporesponsiveness to erythropoietic therapy due to chronic inflammation. Eur J Clin Invest 2005;35 Suppl 3:32-5.

[29] Tan CC, Eckardt KU, Firth JD, Ratcliffe PJ. Feedback modulation of renal and hepatic erythropoietin mRNA in response to graded anemia and hypoxia. Am J Physiol 1992;263:F474-81.

[30] Witthuhn BA, Quelle FW, Silvennoinen O, Yi T, Tang B, Miura O, et al. JAK2 associates with the erythropoietin receptor and is tyrosine phosphorylated and activated following stimulation with erythropoietin. Cell 1993;74:227-36.

[31] Socolovsky M, Nam H, Fleming MD, Haase VH, Brugnara C, Lodish HF. Ineffective erythropoiesis in Stat5a(-/-)5b(-/-) mice due to decreased survival of early erythroblasts. Blood 2001;98:3261-73.

[32] Bouscary D, Pene F, Claessens YE, Muller O, Chretien S, Fontenay-Roupie M, et al. Critical role for PI 3-kinase in the control of erythropoietin-induced erythroid progenitor proliferation. Blood 2003;101:3436-43.

[33] Myklebust JH, Blomhoff HK, Rusten LS, Stokke T, Smeland EB. Activation of phosphatidylinositol 3-kinase is important for erythropoietin-induced erythropoiesis from CD34(+) hematopoietic progenitor cells. Exp Hematol 2002;30:990-1000.

[34] Carroll MP, Spivak JL, McMahon M, Weich N, Rapp UR, May WS. Erythropoietin induces Raf-1 activation and Raf-1 is required for erythropoietin-mediated proliferation. J Biol Chem 1991;266:14964-9.

[35] Orkin SH, Zon LI. Hematopoiesis: an evolving paradigm for stem cell biology. Cell 2008;132:631-44.

[36] Friedman AD. Transcriptional control of granulocyte and monocyte development. Oncogene 2007;26:6816-28. 
[37] Morceau F, Schnekenburger M, Dicato M, Diederich M. GATA-1: friends, brothers, and coworkers. Ann N Y Acad Sci 2004;1030:537-54.

[38] Pevny L, Simon MC, Robertson E, Klein WH, Tsai SF, D'Agati V, et al. Erythroid differentiation in chimaeric mice blocked by a targeted mutation in the gene for transcription factor GATA-1. Nature 1991;349:257-60.

[39] Fujiwara Y, Browne CP, Cunniff K, Goff SC, Orkin SH. Arrested development of embryonic red cell precursors in mouse embryos lacking transcription factor GATA-1. Proc Natl Acad Sci U S A 1996;93:12355-8.

[40] Tsai FY, Orkin SH. Transcription factor GATA-2 is required for proliferation/survival of early hematopoietic cells and mast cell formation, but not for erythroid and myeloid terminal differentiation. Blood 1997;89:3636-43.

[41] Tsai FY, Keller G, Kuo FC, Weiss M, Chen J, Rosenblatt M, et al. An early haematopoietic defect in mice lacking the transcription factor GATA-2. Nature 1994;371:221-6.

[42] Ferreira R, Ohneda K, Yamamoto M, Philipsen S. GATA1 function, a paradigm for transcription factors in hematopoiesis. Mol Cell Biol 2005;25:1215-27.

[43] Ohneda K, Yamamoto M. Roles of hematopoietic transcription factors GATA-1 and GATA-2 in the development of red blood cell lineage. Acta Haematol 2002;108:23745.

[44] Leonard M, Brice M, Engel JD, Papayannopoulou T. Dynamics of GATA transcription factor expression during erythroid differentiation. Blood 1993;82:1071-9.

[45] Tenen DG. Disruption of differentiation in human cancer: AML shows the way. Nat Rev Cancer 2003;3:89-101. 
[46] Zhang P, Zhang X, Iwama A, Yu C, Smith KA, Mueller BU, et al. PU.1 inhibits GATA-1 function and erythroid differentiation by blocking GATA-1 DNA binding. Blood 2000;96:2641-8.

[47] Blobel GA, Nakajima T, Eckner R, Montminy M, Orkin SH. CREB-binding protein cooperates with transcription factor GATA-1 and is required for erythroid differentiation. Proc Natl Acad Sci U S A 1998;95:2061-6.

[48] Collavin L, Gostissa M, Avolio F, Secco P, Ronchi A, Santoro C, et al. Modification of the erythroid transcription factor GATA-1 by SUMO-1. Proc Natl Acad Sci U S A $2004 ; 101: 8870-5$

[49] Liew CK, Simpson RJ, Kwan AH, Crofts LA, Loughlin FE, Matthews JM, et al. Zinc fingers as protein recognition motifs: structural basis for the GATA-1/friend of GATA interaction. Proc Natl Acad Sci U S A 2005;102:583-8.

[50] Buck I, Morceau F, Grigorakaki C, Dicato M, Diederich M. Linking anemia to inflammation and cancer: the crucial role of TNFalpha. Biochem Pharmacol $2009 ; 77: 1572-9$.

[51] Ferreira R, Wai A, Shimizu R, Gillemans N, Rottier R, von Lindern M, et al. Dynamic regulation of Gata factor levels is more important than their identity. Blood 2007;109:5481-90.

[52] Grass JA, Boyer ME, Pal S, Wu J, Weiss MJ, Bresnick EH. GATA-1-dependent transcriptional repression of GATA-2 via disruption of positive autoregulation and domain-wide chromatin remodeling. Proc Natl Acad Sci U S A 2003;100:8811-6.

[53] Ikonomi P, Rivera CE, Riordan M, Washington G, Schechter AN, Noguchi CT. Overexpression of GATA-2 inhibits erythroid and promotes megakaryocyte differentiation. Exp Hematol 2000;28:1423-31. 
[54] Whyatt D, Lindeboom F, Karis A, Ferreira R, Milot E, Hendriks R, et al. An intrinsic but cell-nonautonomous defect in GATA-1-overexpressing mouse erythroid cells. Nature 2000;406:519-24.

[55] Whyatt DJ, Karis A, Harkes IC, Verkerk A, Gillemans N, Elefanty AG, et al. The level of the tissue-specific factor GATA-1 affects the cell-cycle machinery. Genes Funct 1997;1:11-24.

[56] La Ferla K, Reimann C, Jelkmann W, Hellwig-Burgel T. Inhibition of erythropoietin gene expression signaling involves the transcription factors GATA-2 and NF-kappaB. Faseb J 2002;16:1811-3.

[57] Stopka T, Amanatullah DF, Papetti M, Skoultchi AI. PU.1 inhibits the erythroid program by binding to GATA-1 on DNA and creating a repressive chromatin structure. EMBO J 2005;24:3712-23.

[58] DeKoter RP, Singh H. Regulation of B lymphocyte and macrophage development by graded expression of PU.1. Science 2000;288:1439-41.

[59] Ito T, Nishiyama C, Nishiyama M, Matsuda H, Maeda K, Akizawa Y, et al. Mast cells acquire monocyte-specific gene expression and monocyte-like morphology by overproduction of PU.1. J Immunol 2005;174:376-83.

[60] Weiss MJ, Keller G, Orkin SH. Novel insights into erythroid development revealed through in vitro differentiation of GATA-1 embryonic stem cells. Genes Dev 1994;8:1184-97. 


\section{Figure Legends}

Figure 1: Characterization of the ${\mathrm{CD} 34^{+}}^{+}$isolated population. The purity of $\mathrm{CD} 34^{+}$cells obtained after isolation was assessed by flow cytometry. The average purity was approximately $96 \%$. In parallel, the presence of hematopoietic markers, such as CD36, GPA, CD41a, CD11b, CD24, and CD38 were evaluated. One representative experiment out of three is shown here.

Figure 2: In vitro erythropoiesis and the effect of TNF $\alpha$ on erythroid morphology, development and differentiation. A. Giemsa staining at days (D) 2, 3, 5, and 8 of culture in EPO-differentiated cells treated with TNF $\alpha(20 \mathrm{ng} / \mathrm{mL})$ or left untreated. Untreated cells from day 0 were used as a control. Red arrows: proerythroblasts; black arrows: polychromatic erythroblasts; blue arrows: orthochromatic erythroblasts; green arrows: enucleating reticulocytes; orange arrows: reticulocyte-like cells. Control, D2 and D3 images were captured using a 40x objective, and D5 and D8 were captured using a 100x objective. B. Benzidine staining was performed on EPO-differentiated cells treated with $20 \mathrm{ng} / \mathrm{mL}$ of TNF $\alpha$ or left untreated for 3 and 4 days. (*: $\mathrm{P}<0.05$ ). C. Flow cytometry was used to evaluate the evolution of the erythroid specific markers, CD36 and GPA/CD235a, after 4 and 9 days of TNF $\alpha$ treatment. D. Cell proliferation of HSPCs in the presence of EPO only or EPO/TNF $\alpha$.

Figure 3: Effect of TNF $\alpha$ on GATA-1 transcriptional activity A. TF1 cells were cotransfected with the GATA-1-expressing vector, pXM-GATA1 and the reporter luciferase plasmids, pGL3-GATA-Luc and pHRG-TK. Transfected cells were treated for $2 \mathrm{~h}$ with TNF $\alpha$ or left untreated prior to analysis of luciferase activity. Firefly activity was normalized to Renilla, and the results are expressed as a ratio in arbitrary units. The data are presented as mean \pm S.D. of three independent experiments. (**: $\mathrm{P} \leq 0.01$ and $* * *: \mathrm{P}<0.001)$. B. GATA-1 
protein expression in TF1 cells cultured in the presence of GM-CSF (GM) or GM-CSF and TNF $\alpha$ (GM/TNF) was assessed by western blot analysis. Nuclear extracts from human erythroleukemia HEL cells were used as a positive control. $\beta$ actin was used as an internal control.

Figure 4: Effect of TNF $\alpha$ on erythroid-specific transcription factors. A. EPOdifferentiated cells were treated with TNF $\alpha$ or left untreated for 4 days. Total RNA was extracted and subjected to reverse transcription and real-time PCR. Results were calculated by $\triangle \mathrm{CT}$ method and normalized to the housekeeping gene, GAPDH. B. EPO-differentiated cells were treated with TNF $\alpha$ or left untreated, and nuclear factors were extracted on days 2, 3 and 4. GATA-1, GATA-2 and PU.1 expression were analyzed by western blot. $\beta$ actin was used as an internal control. One experiment out of three independent experiments is shown. $\mathbf{C}$. EPO-stimulated $\mathrm{CD} 34^{+}$cells were treated with TNF $\alpha$ or left untreated for 4 days. Nuclear (nucl) and cytoplasmic (cyto) proteins were extracted and GATA-1 was immunoprecipitated using GATA-1 (C20X) antibody. GATA-1 (N1) and PU.1 (T-21) antibodies were then used to reveal GATA-1 and PU.1 by immunoblotting. One out of three independent experiments is shown.

Figure 5: Effect of TNF $\alpha$ on erythroid-specific gene expression A. EPO-stimulated CD34 ${ }^{+}$ cells were treated with TNF $\alpha$ or left untreated for 4 days. Total RNA was extracted and submitted to reverse transcription and real-time PCR using specific primers for GPA (glycophorin A), EPOR (erythropoietin receptor), HB (hemoglobin), CD41b and CD11b genes. $\triangle \mathrm{CT}$ values were calculated and normalized to the GAPDH housekeeping gene. (*: P values $<0.05$; **: $\mathrm{P}$ values $<0.01)$. B. Western blot analysis of $\alpha$-globin, $\beta$-globin, $\gamma$-globin and 
EPOR in total protein extracts from $\mathrm{CD}_{3} 4^{+}$cells treated with TNF $\alpha$ or left untreated for 2, 3 and 4 days. $\beta$ actin was used as an internal control. One out of three independent experiments is shown.

Figure 6: Effect of TNF $\alpha$ on isolated $\mathrm{GPA}^{+}$cells. HSPC cells were treated with TNF $\alpha$ or left untreated for 9 days. $\mathrm{GPA}^{+}$cells were then isolated and the nuclear and cytoplasmic protein extracts were used to perform western blot analysis of the transcription factors GATA-1, GATA-2 and PU.1 and the $\alpha-, \beta-$ and $\gamma$-globin. $\beta$ actin was used as an internal control. One out of three independent experiments is shown. 
Figure 1
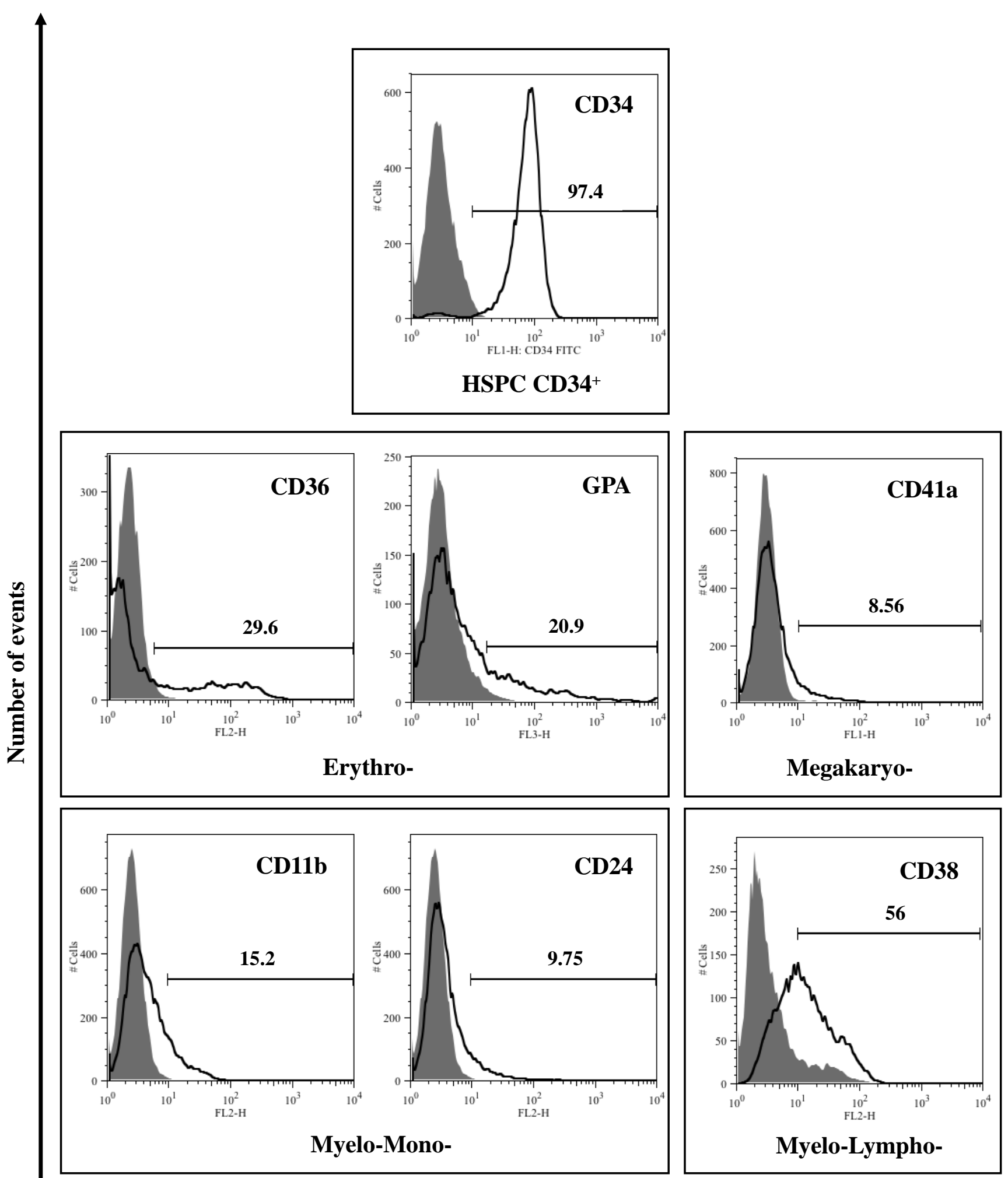

Fluorescent intensity 
Figure 2

C

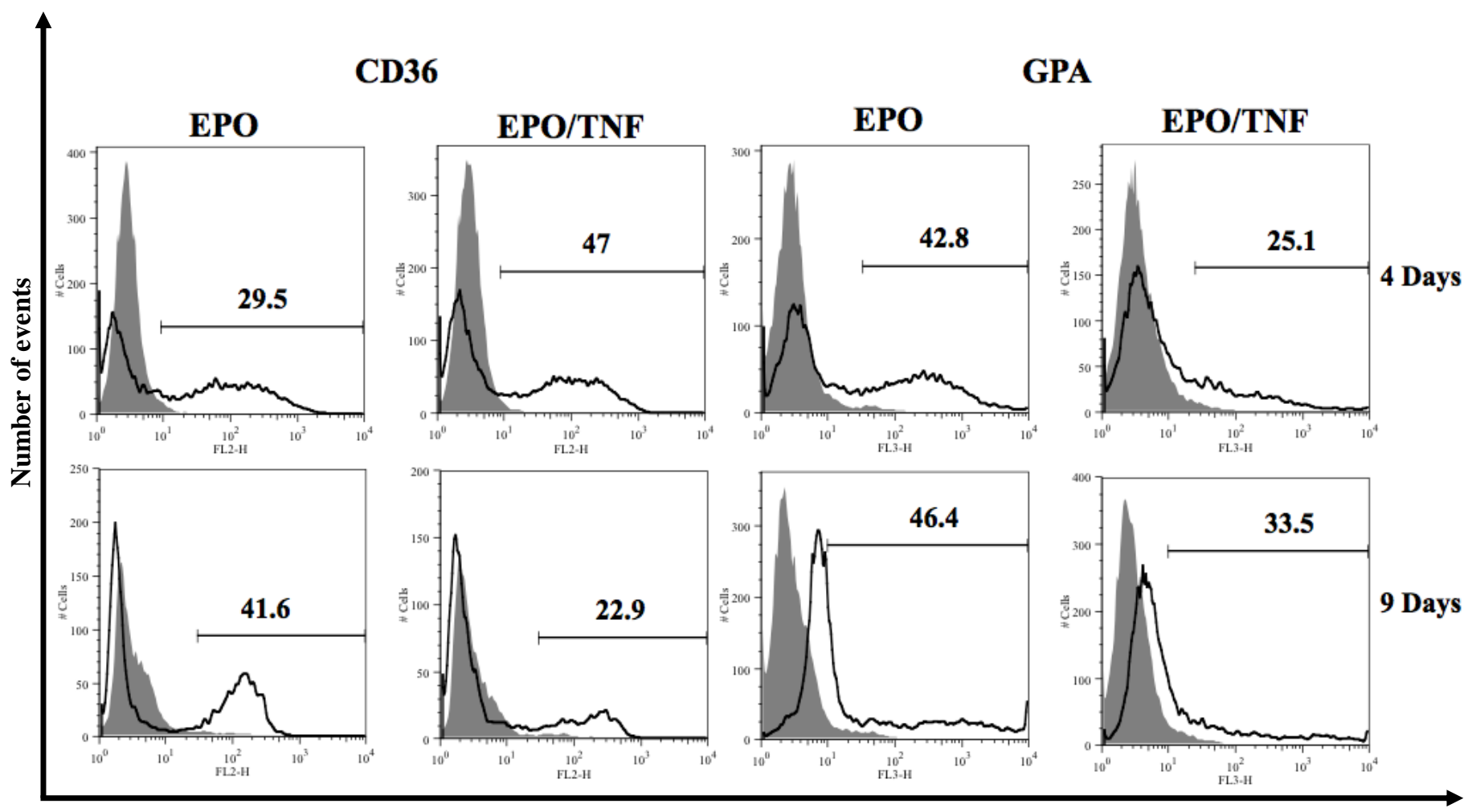

Fluorescent intensity
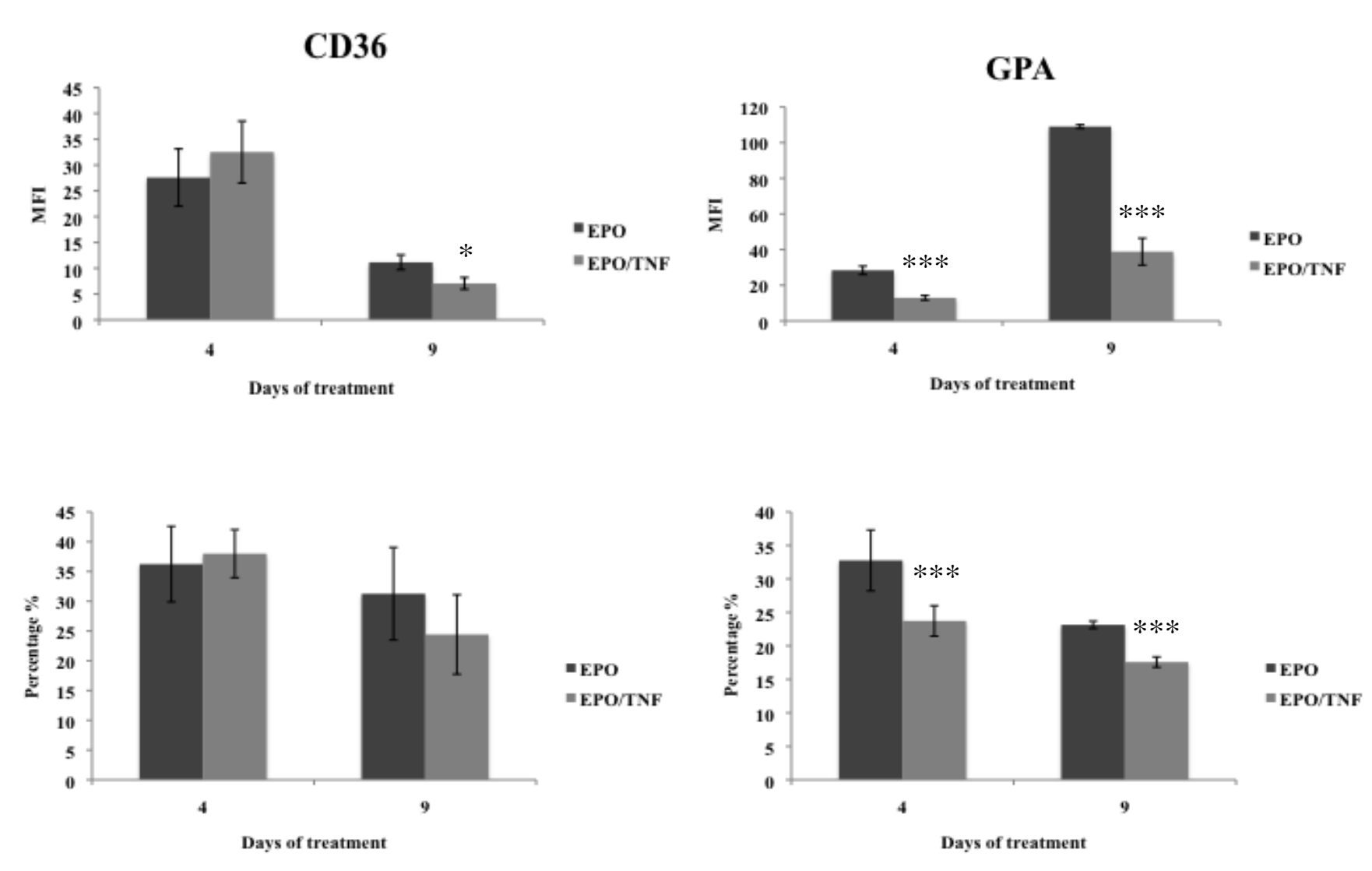
Figure 2

A
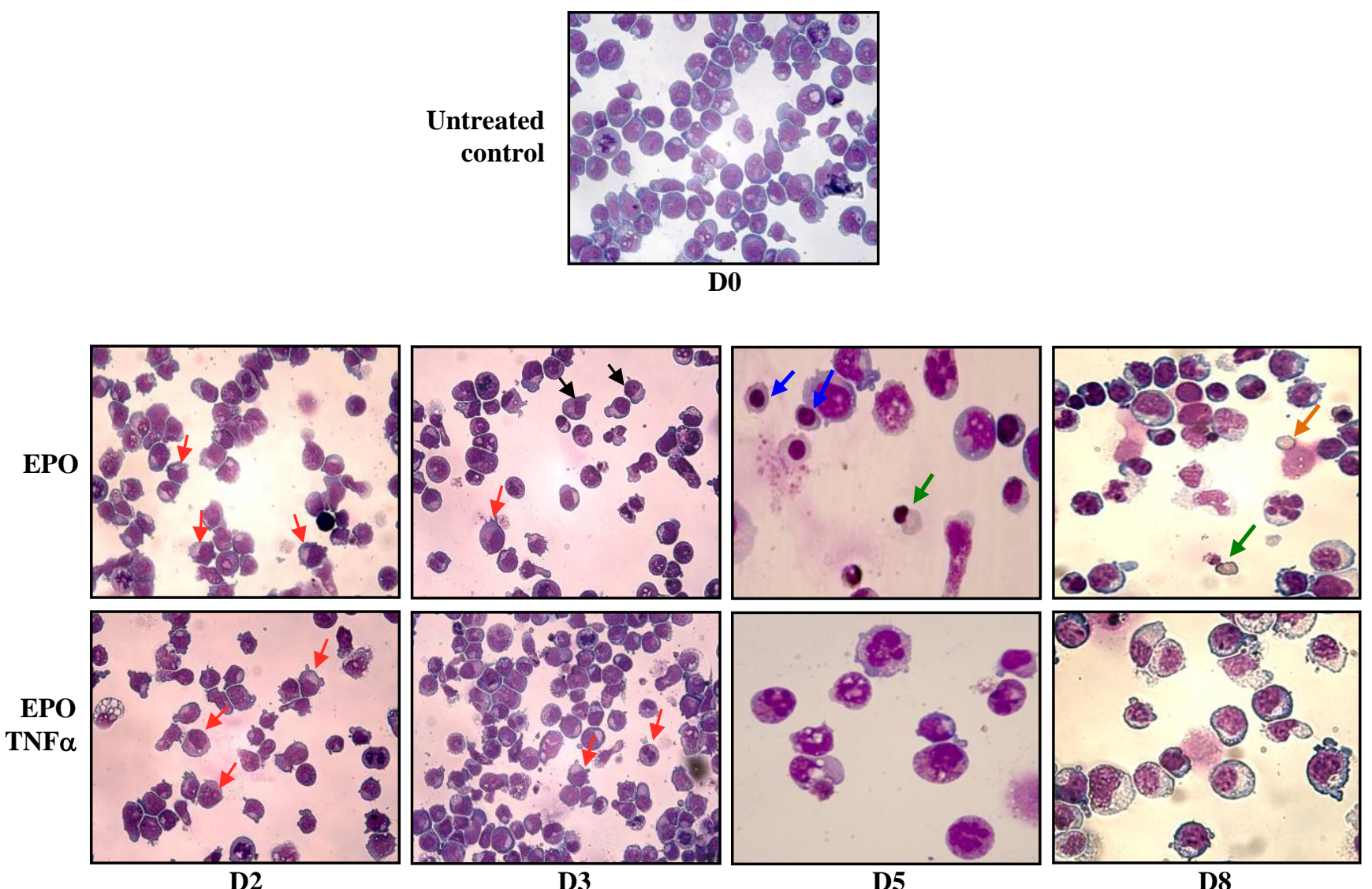

B

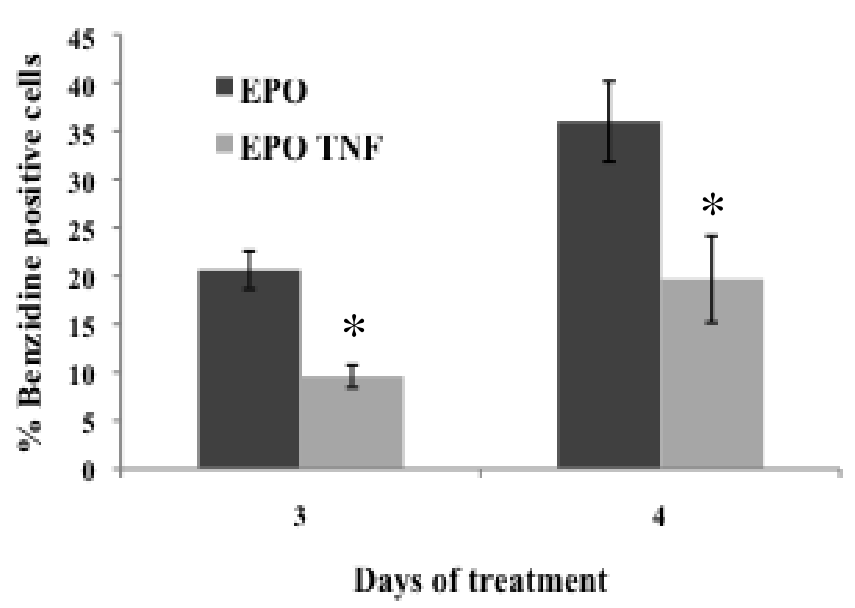


Figure 2

D

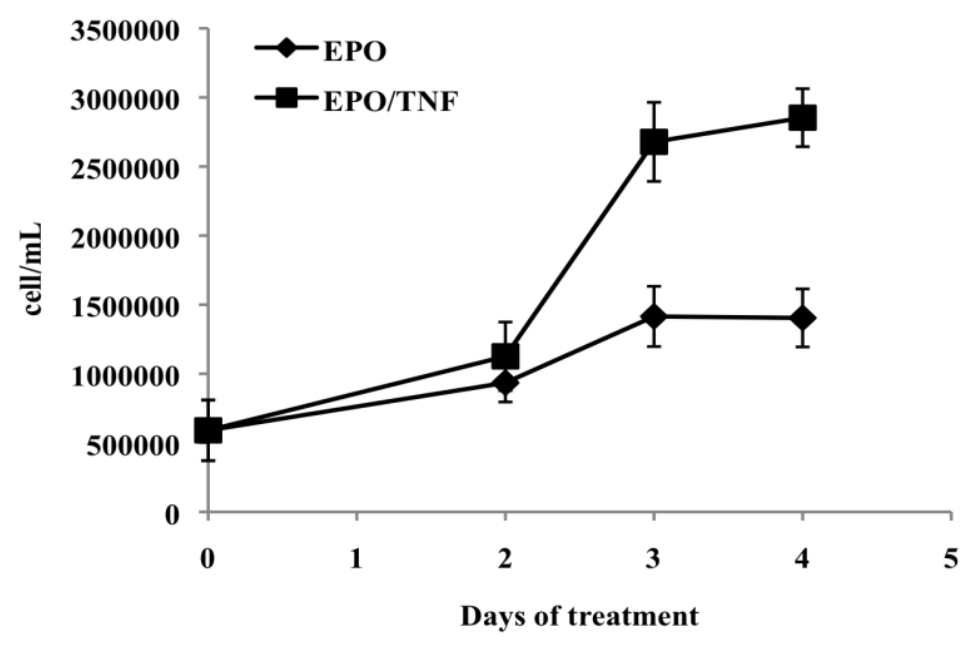


Figure 3

A

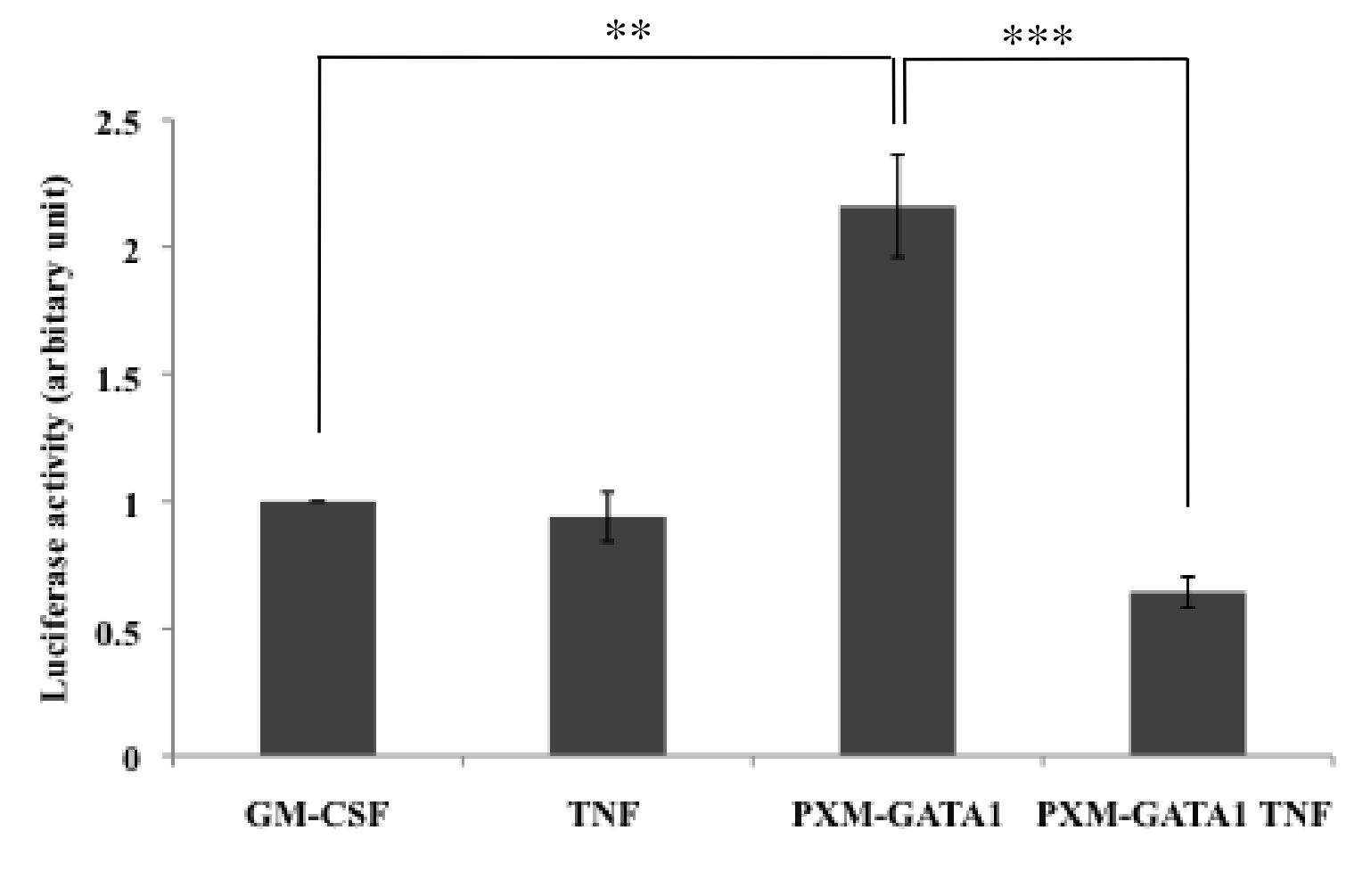

B

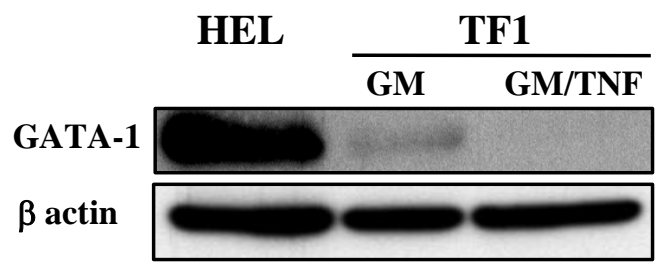


Figure 4

A

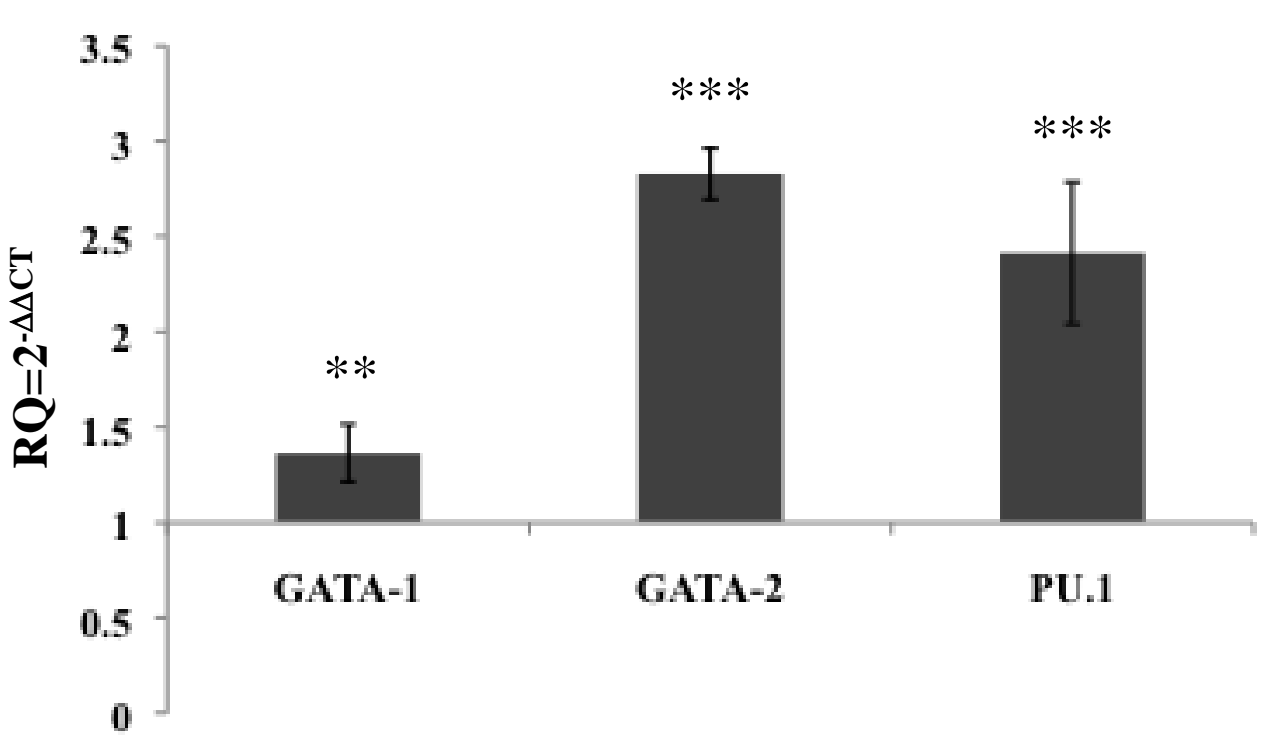

B
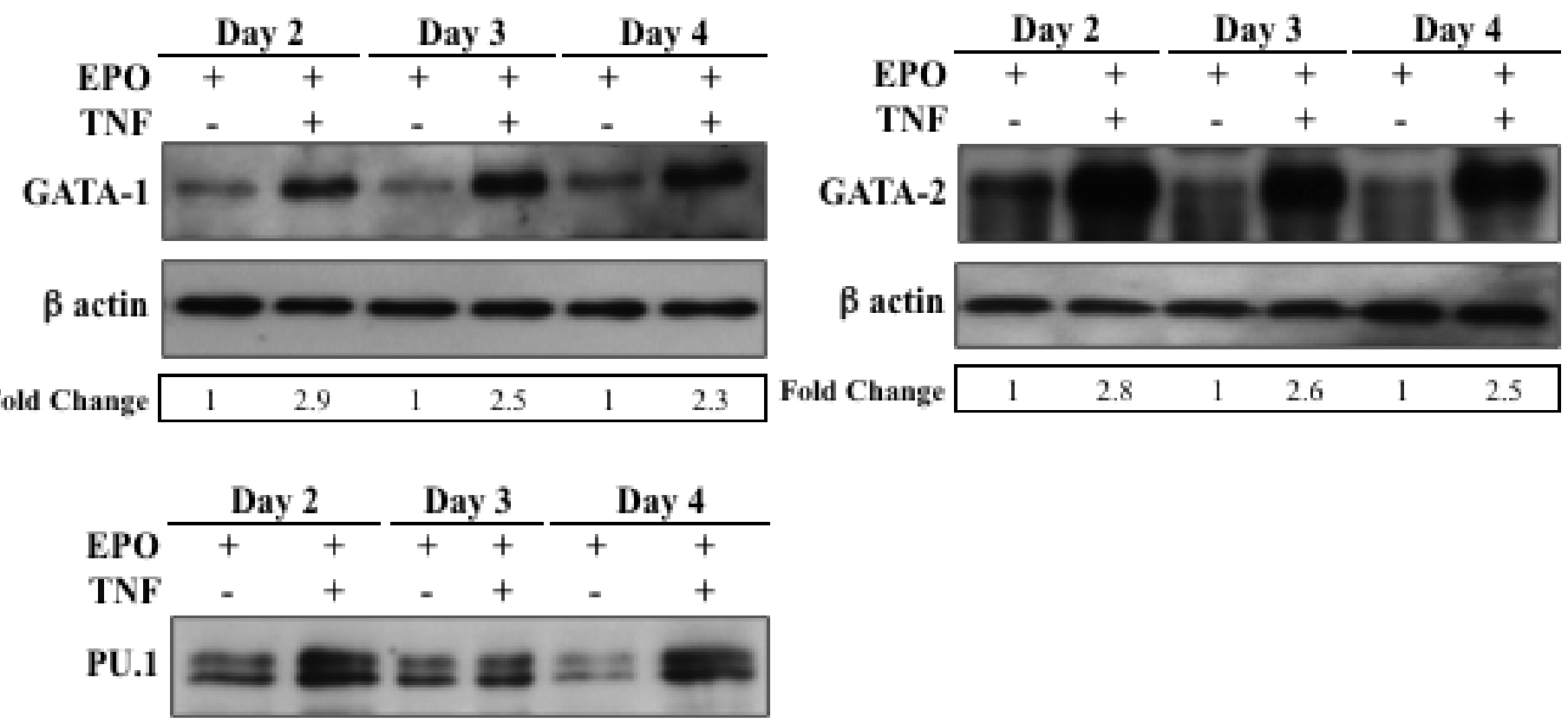

$\beta$ actin

Fold Change

\begin{tabular}{lllll}
1.3 & 1 & 1.1 & 1 & 2.3 \\
\hline
\end{tabular}

C

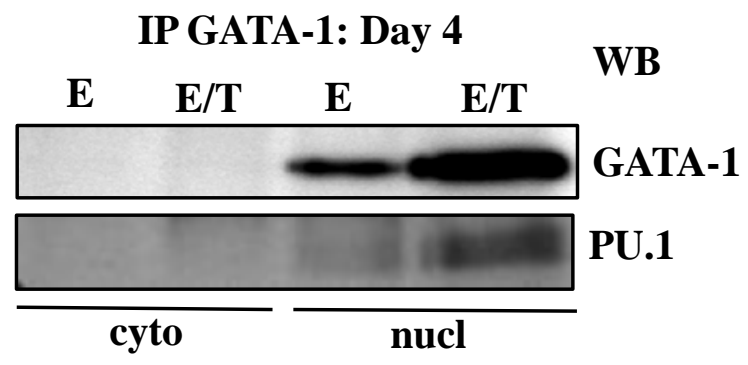


Figure 5

A

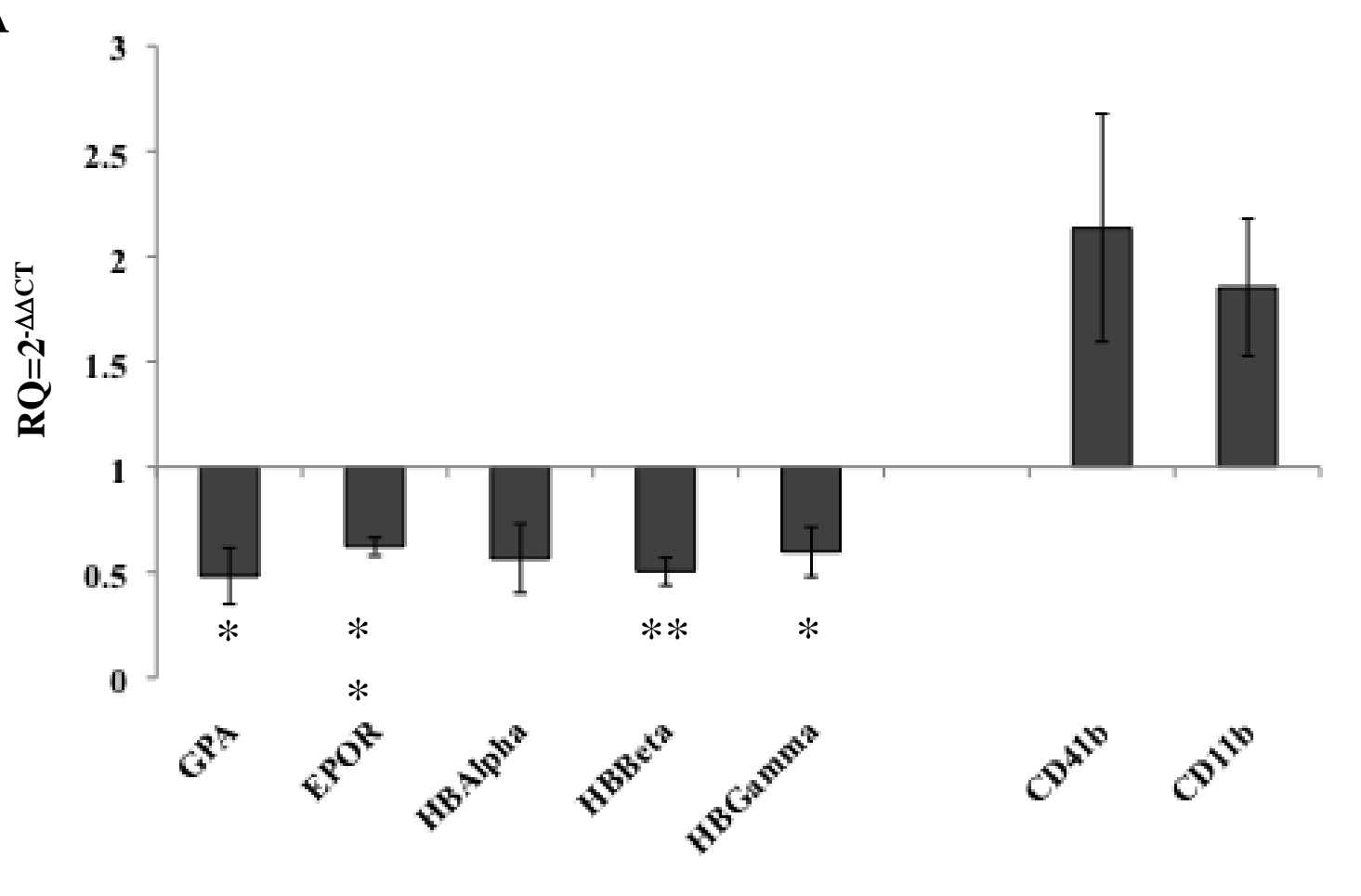

B

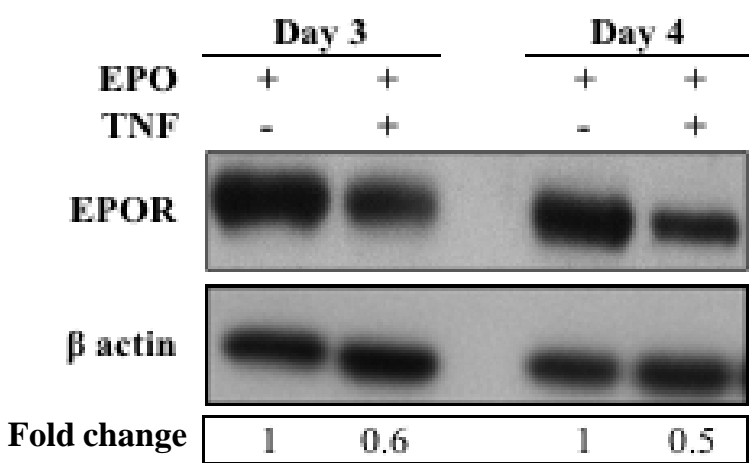

\begin{tabular}{|c|c|c|c|c|c|c|}
\hline \multirow[b]{2}{*}{ EPO } & \multicolumn{2}{|c|}{ Day 2} & \multicolumn{2}{|c|}{ Day 3} & \multicolumn{2}{|c|}{ Day 4} \\
\hline & + & + & + & + & + & + \\
\hline TNF & - & + & - & + & - & + \\
\hline
\end{tabular}

$\beta$-globin
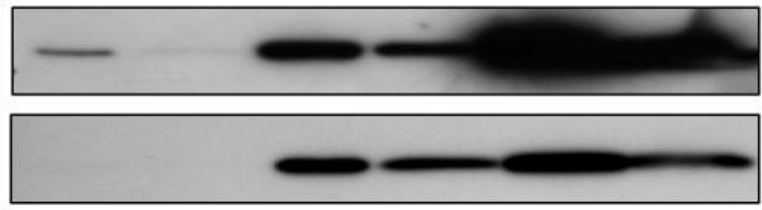

less exposed

$\gamma$-globin

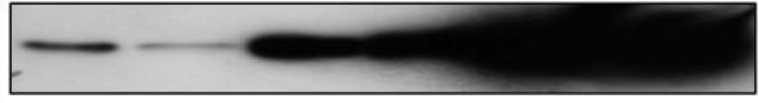

less exposed

$\beta$ actin

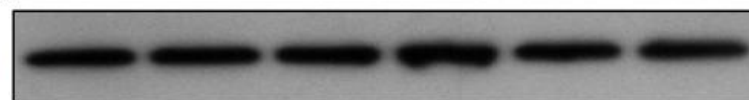


Figure 6
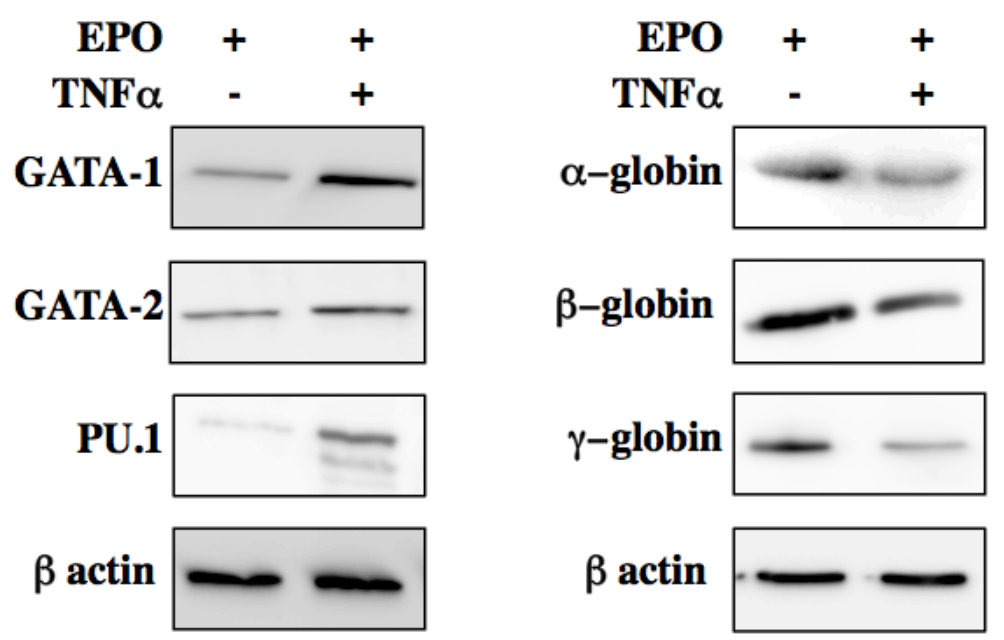


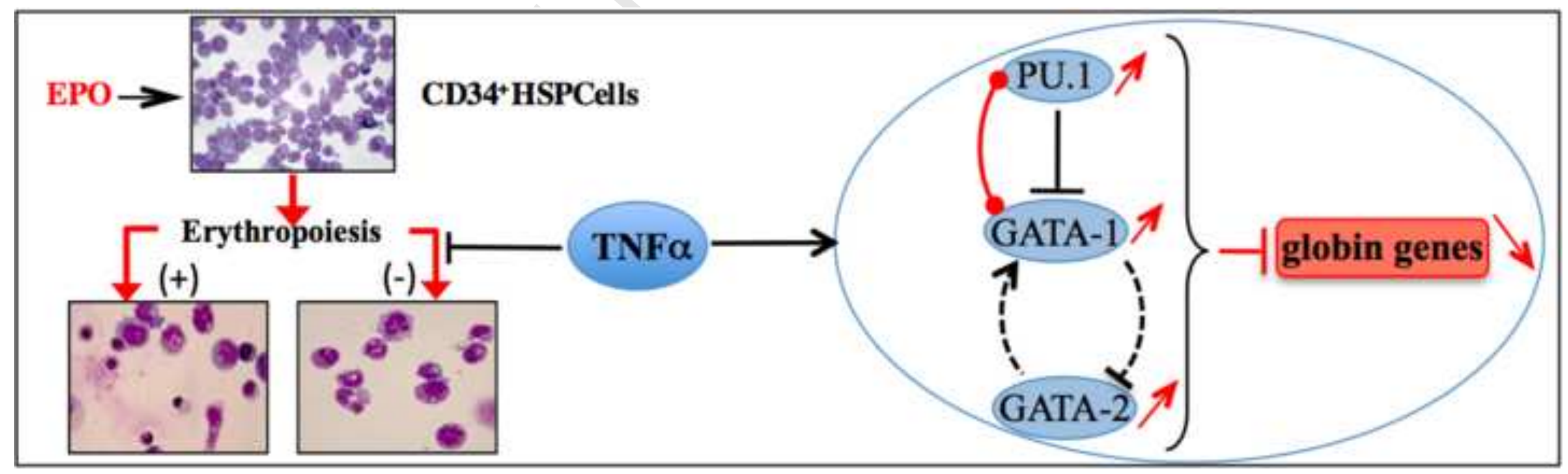

